\title{
Rehabilitation of a green sea turtle (Chelonia mydas) after collision with motorboat in the archipelago of Fernando de Noronha, Brazil
}

\begin{abstract}
Augusto Carlos da Bôaviagem Freire ${ }^{1,2 *}$, Radan Elvis Matias de Oliveira ${ }^{1,2,3}$, Juliana Maia de Lorena Pires $^{1,2}$, Fernanda Löffler Niemeyer Attademo², Amy Borges Moreira ${ }^{4}$, Lucas Inácio dos Santos Melo ${ }^{1,3}$, Marcus Arthur Marques Dantas ${ }^{1}$, Daniel Solon Dias de Farias ${ }^{1,2,5,6}$, Aline da Costa Bomfim ${ }^{1,25,6,}$, Claudio Bellini', Simone Almeida Gavilan 1,2,6, Flávio José de Lima Silva ${ }^{1,2,4,6}$

${ }^{1}$ Projeto Cetáceos da Costa Branca, Universidade do Estado do Rio Grande do Norte, Mossoró, RN, Brazil.

${ }^{2}$ Centro de Estudos e Monitoramento Ambiental, Areia Branca, RN, Brazil.

${ }^{3}$ Programa de Pós-Graduação em Ciência Animal, Universidade Federal Rural do Semi-Árido, Mossoró, RN, Brazil.

${ }^{4}$ Programa de Pós-Graduação em Ciências Naturais, Universidade do Estado do Rio Grande do Norte, Mossoró, RN, Brazil.

${ }^{5}$ Programa de Doutorado em Desenvolvimento e Meio Ambiente, Universidade Federal do Rio Grande do Norte, Natal, RN, Brazil.

${ }^{6}$ Programa de Pós-Graduação em Biologia Estrutural e Funcional, Departamento de Morfologia, Centro de Biociências, Universidade Federal do Rio Grande do Norte, Natal, RN, Brazil.

${ }^{7}$ ICMBio - Instituto Chico Mendes de Conservação da Biodiversidade, Fernando de Noronha, PE, Brazil.
\end{abstract}

${ }^{*}$ Corresponding author: Augusto Carlos da Bôaviagem Freire. Avenida Professor Antônio Campos, $n^{0}$ S/N Presidente Costa e Silva. Zip Code: 59625-620 - Mossoró, RN, Brazil. Phone: +55 (84) 9 8116-3642. E-mail: pxboaviagem@gmail.com.

Research Ethics Committee Approval (if necessary): Not applied.

Received on: Jul 29, 2021. Accepted on: Aug 6, 2021. Available online: Aug 11, 2021.

\begin{abstract}
A juvenile green sea turtle (Chelonia mydas) of undetermined sex was rescued on October 16, 2019, in the archipelago of Fernando de Noronha, Pernambuco, Brazil. The animal was presence of active bleeding resulting from two transverse fractures in the carapace, with exposure of the coelomic cavity. Radiological and hematological tests were performed. The animal received therapeutic support and surgical reconstruction of the carapace. The animal was medically cleared and reintroduced into the natural environment 120 days after it was rescued. The protocol used here for both the rehabilitation and the surgical procedure was concluded to be effective.
\end{abstract}

Keywords: Carapace fracture; Reconstruction; Traumatic; Cheloniidae; Testudines.

\section{Introduction}

Sea turtles have a complex and long life cycle, making them susceptible to threats caused by natural, biological, and/or anthropic factors at all developmental stages [1], [2], [3], [4], [5], 
[6]. Traumatic injuries considerably affect sea turtles; these may occur as a result of predator bites, fishing interactions with oil and natural gas exploration/production activities, motorized boat collisions, and hopper dredging [7], [8], [9], [10].

Of the seven species found worldwide, green turtles (Chelonia mydas) account for most of the reported deaths caused by boat collisions [11], which may be due to several factors, especially the coastal habit of the species [12].

Traumatic injuries may not cause death immediately, but lead to disorientation and weakness, and may serve as entry points for pathogens that then act as immunosuppressants and promote the development of opportunistic infections [13], [14].

Most scientific publications have focused on collisions between boats and North Atlantic whales [15], [16], and there is a scarcity of information on collisions of boats with smaller species, and with all animals in the South Atlantic [17]. In this context, we herein report the first case of a successful rehabilitation of a sea turtle victim of a collision with a motorized boat in the archipelago of Fernando de Noronha, Pernambuco, Brazil.

\section{Case report}

A juvenile green turtle (Chelonia mydas) was rescued after a traumatic injury to the carapace on October 16, 2019, by the technical team of the TAMAR Project (Tamar Center -
ICMBio) in Porto de Santo Antônio $\left(03^{\circ} 50^{\prime} 04^{\prime \prime} \mathrm{S}, 032^{\circ} 24^{\prime} 05^{\prime \prime} \mathrm{W}\right)$ in the archipelago of Fernando de Noronha, Pernambuco, Brazil. The animal had a good body condition score, $7.1 \mathrm{~kg}$ live weight, with $40.5 \mathrm{~cm}$ curved carapace length and $35 \mathrm{~cm}$ curved carapace width. The animal presented with severe agitation, slightly noisy and accelerated breathing, tachycardia, active bleeding, and traumatic injuries.

Transverse fractures of the carapace, one in the anterior region on the second vertebral shield and corresponding secondary structures including the lateral and marginal shield on the right side (Figure 1A), and the second, posterior, fracture on the fourth vertebral shield with trauma to the lateral shields on both left and right sides (Figure 1B), exposing the coelomic cavity. The edges of the fractures were active and moved easily in accordance with the animal's movements. According to these findings and information collected at the stranding site, the animal was a victim of collision with the propeller of a motorized boat.

After clinical stabilization for 48

$h$, the turtle was transferred by air to the city of Natal, Rio Grande do Norte (RN, Brazil) for further examination, and later sent by overland transportation to the Rehabilitation Center for Marine Fauna of the Costa Branca Cetacean Project of the State University of Rio Grande do Norte, in the municipality of Areia Branca, RN. 


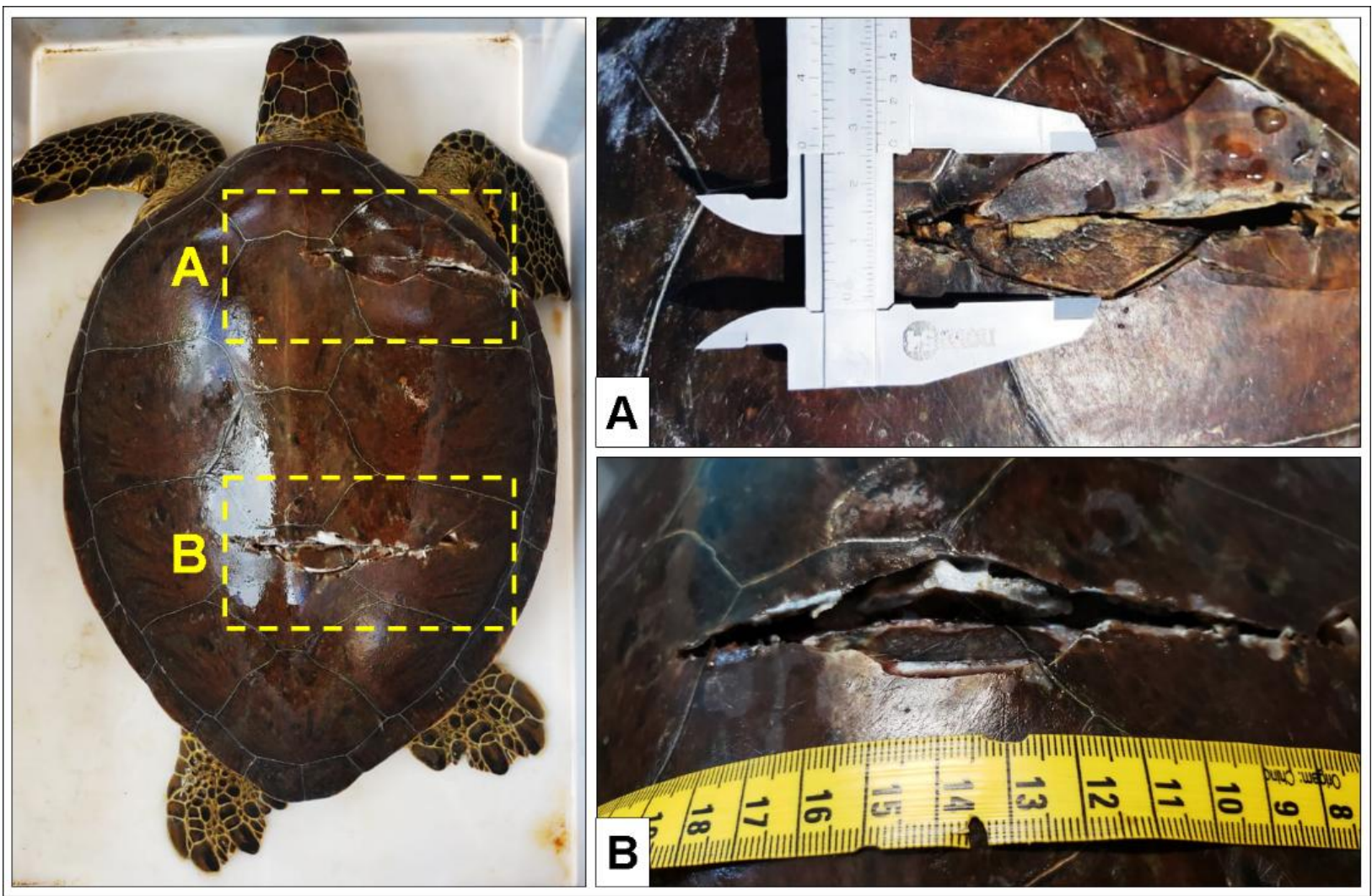

Figure 1. Green turtle (Chelonia mydas) injuries after motor boat collision. (A) Transverse fractures on the second vertebral shield and secondary structures (first lateral and marginal shield, right side). (B) Fractures on the fourth vertebral shield and on the third lateral shields (both sides).

\section{Radiographic evaluations} revealed two fracture lines on the animal's carapace. The first fracture (anterior region) extended from the neural bone through the first right pleural bone to the peripheral bone, and the second fracture (posterior region) extended from the neural bone to the fifth right pleural bone (Figure 2A to $2 \mathrm{C})$.

Hematological examination revealed hypochromic microcytic anemia, leukocytosis with high heterophile, lymphocyte, basophil, and monocyte cell counts, and low total protein levels. Considering these findings and the poor clinical parameters, which demonstrated severe systemic instability, clinical stabilization was prioritized before proceeding with surgical reconstruction of the carapace.

The animal was kept out of the water to avoid contamination of the wound, and on damp cloths to avoid total dryness of the carapace and mucous membranes. For 15 days, the open wounds were treated with topical application of sterile $0.9 \% \mathrm{NaCl}$ solution followed by a supersaturated solution of granulated sugar and filtered water 
(1:1). Supportive treatment consisted of electrolyte replacement by mixed fluid therapy (1:3) with $0.9 \%$ sodium chloride $+5 \%$ glucose + lactated Ringer's solution (KabiPac®, 20 mL/kg IV q.72 h for 15 days) diluted with a multivitamin, mineral, and amino acid complex (Bionew $^{\circledR}, 0.2 \mathrm{~mL} / \mathrm{kg}$ IV q.72 $\mathrm{h}$ for 15 days). For presurgical therapy, the following were prescribed: the antibiotic ceftiofur hydrochloride (Bioxell ${ }^{2}, 2$ $\mathrm{mg} / \mathrm{kg}$ IM $\mathrm{q} .24 \mathrm{~h}$ for 30 days), the analgesics tramadol hydrochloride and sodium dipyrone $\left(\right.$ Tramal $^{\circledR}, 5 \mathrm{mg} / \mathrm{kg}$ IM q.72 $\mathrm{h}$ for 15 days and D-500 ${ }^{\circledR}, 25 \mathrm{mg} / \mathrm{kg}$ IM q.8 h for 15 days), and a meloxicambased anti-inflammatory (Maxicam ${ }^{\circledR}, 0.2$ $\mathrm{mg} / \mathrm{kg}$ IM q.24 h for 5 days).

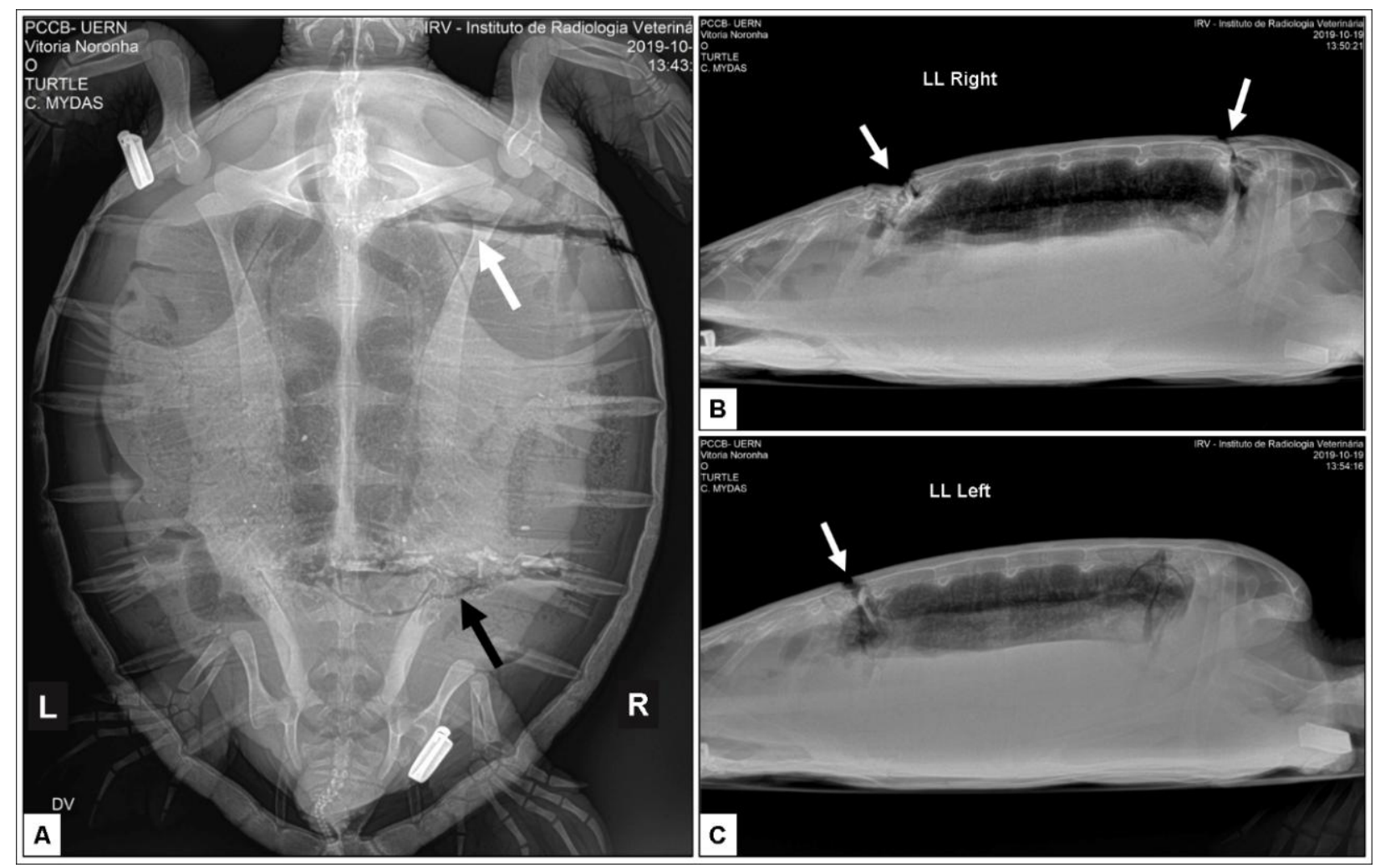

Figure 2: Radiographic examination of a green turtle (Chelonia mydas) with injuries due to collision with a motorboat. (A) Dorsoventral projection showing two transverse bone fractures. The first fracture was located in the anterior region (white arrow) and extended from the neural bone through the first right pleural bone to the peripheral bone, and the second, in the posterior region(black arrow), extended from the neural bone to the fifth right pleural bone. (B and C) Right and left laterolateral projections, respectively, showing fractures in the neural bones without spinal cord involvement (arrows).

After clinical stabilization, the turtle was referred for surgical reconstruction of the carapace. The turtle was positioned in dorsal 
recumbency, tramadol hydrochloride was given at $5 \mathrm{mg} / \mathrm{kg} \mathrm{IM}$ as a preanesthetic medication, and anesthesia was induced by inhalation of $4 \%$ isoflurane via a vaporizer with $100 \%$ oxygen by mask. The trachea was intubated with a cuffed endotracheal tube. The time from induction to extubation was 110 minutes. After intubation, anesthesia was maintained with $2 \%$ sevoflurane via a vaporizer. The turtle moved when we started the operation, so anesthesia was changed to isoflurane at a concentration of $3.5-4.0 \%$ during the surgical procedure. The endtidal $\mathrm{CO}_{2}$ partial pressure immediately after intubation was $63 \mathrm{mmHg}$ and was maintained at $22-46 \mathrm{mmHg}$ during

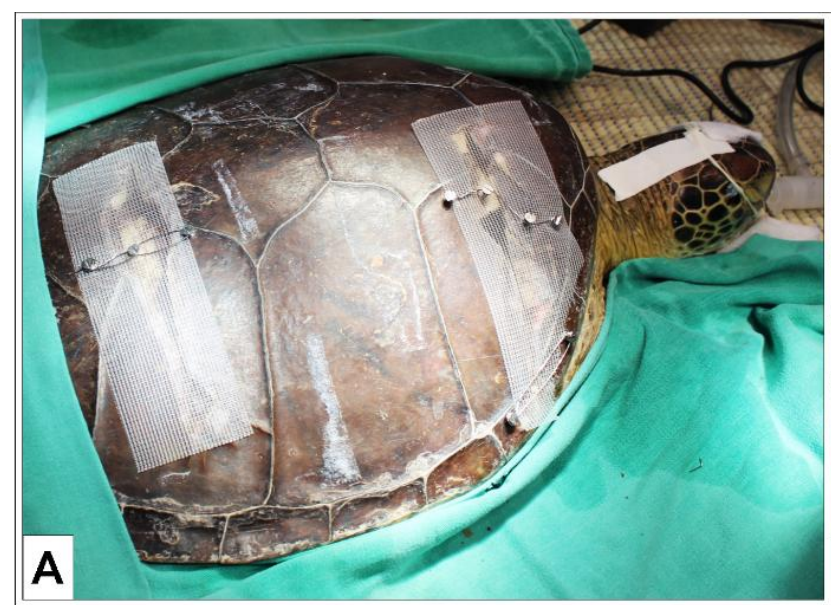

surgery using artificial ventilation as needed. All unstable fracture fragments of the lesions were removed, $15 \mathrm{~mm}$ steel cannulated conical screws were fixed at the edges of the fracture line, and $0.8 \mathrm{~mm}$ steel cerclage wire was used to approximate the edges to support regeneration of discontinuous structures (Figure 3A).

Afterward, a polypropylene Marlex mesh (Intracorp $\AA$ ) and resin were applied for anatomical restoration of the carapace to prevent entanglement with marine debris and to minimize adhesion of epibionts around the implanted material in the post-release period (Figure $3 \mathrm{~B}$ ).

Figure 3: Surgical procedure in green turtle (Chelonia mydas) with injuries due to collision with motor boat. (A) Screw fixation at the lesion's widest points and approximation of the edges with cerclage wire, with a polypropylene marlex mesh covering the lesions. (B) After completing the surgical procedure, with the carapace reconstituted with application of resin.

After surgery, the turtle was kept in an area with low water depth, between 5 and $10 \mathrm{~cm}$ in height, to keep the nasal and oral cavities hydrated.
Due to an absence of interest in food, a formulation based on fish paste and vitamin supplementation was administered enterally every $72 \mathrm{~h}$ for 20 days, until the animal showed total 
interest in spontaneous feeding with fish and seaweed. Twenty-eight days after surgery, the turtle was transferred to a $1 \mathrm{~m}^{3}$ circular area with salt water and showed satisfactory motor activity and no buoyancy impairments. The animal was medically cleared and reintroduced to the natural environment (0455'50.1" S-3706'52.3" W) 120 days after rescue.

\section{Discussion and Conclusion}

Turtle injuries resulting from trauma caused by collisions with boats usually include multiple carapace and plastron fractures, which are difficult to restore [18], [19], [13]. The type and severity of the injuries may depend on the part of the boat that collides with the animal [19], [13]. In particular, propellers produce multiple wounds that are linear, parallel, penetrating, and regularly spaced at a given angle [13]. These findings were also observed in the present case report.

Several techniques have been described for carapace repair, including epoxy resin, screws, wires, and metal plates [20], [21]. However, each technique should be evaluated for the specificities of trauma and the animal's physical and clinical conditions [18]. In addition to fracture, soft tissue injuries with secretion leakage, immediate repair, or use of epoxy-type materials for repair can prevent drainage and cleaning of the underlying wound. This increases the risk of systemic infection, which supports the need for caution and attention when selecting the method to be used [22].

The clinical stabilization and presurgical treatment recommended in this report proved to be effective in controlling pain and infection. The topical use of a supersaturated sugar solution, in addition to keeping the injured tissue viable, contributed to tissue remodeling and wound healing [23], [24], [25], [26].

The healing time reported for carapace damage in turtles is quite variable, as some reports indicate 3 to 9 months [27] and others up to 30 months [28]. In this case, complete wound healing of the affected regions was observed after 115 days.

The good body condition and hydration of the animal at the time of stranding were fundamental to the period in which the turtle was fasted and had to be kept in an area out of the water, with only parenteral nutrition. During this phase, parenteral nutrition provides the minimum necessary conditions until surgical reconstruction of the carapace is performed.

The protocol used here for both rehabilitation and surgical procedures proved to be effective and can be used in similar cases. The animal's early adaptation to the implanted artifacts and the fast regain of an interest in food were essential to the animal's rapid response in attaining satisfactory conditions, accelerating its return to nature. 


\section{References}

[1] Barten SL. Shell damage. In: Mader DR, editor. Reptile medicine and surgery. Florida: Marathon; 2006. pp. 893-9.

[2] Sellera FP, Fernandes LT, Texeira CR, Pogliani FC, Dutra GHP, Nascimento CL. Terapia fotodinâmica na consolidação de fratura de carapaça em tartaruga-verde (Chelonia mydas). Nat. Resour. 2013 Feb 4;3(1):49-55. Portuguese.

[3] Farias DSD, Alencar AEB, Bomfim AC, Fragoso ABL, Rossi S, Moura GJB, Gavilan AS, Silva FJL. Marine Turtles Stranded in Northeastern Brazil: Composition, Spatio-temporal, Distribution and Anthropogenic Interactions. Chelonian Conserv. Biol. 2019 Jun 5;18(1):1-8.

[4] Silva-Júnior ES, Farias DSD, Bomfim AC, Freire ACB, Revorêdo RA, Rossi S, Matushima ER, Grisi-Filho JHH, Silva FJL, Gavilan SA. Stranded Marine Turtles in Northeastern Brazil: Incidence and Spatial-Temporal Distribution of Fibropapillomatosis. Chelonian Conserv. Biol. 2019 Oct 18;18(2):249-58.

[5] Tagliolatto AB, Goldberg DW, Godfrey $\mathrm{MH}, \quad$ Monteiro-Neto C. Spatio-temporal distribution of sea turtle strandings and factors contributing to their mortality in south-eastern Brazil. Aquatic Conserv: Mar Freshw Ecosyst. 2019 Dec 14;30(2):331-50.

[6] Oliveira REM, Pires JML, Batista JS, Attademo FLN, Farias DSD, Freire ACB, Bomfim AC, Lima LRP, Oliveira RM,
Gavilan SA, Silva FJL, Oliveira MF (2020): Death of a loggerhead sea turtle (Caretta caretta) from ingestion of an eel (Myrichthys ocellatus). Vet. Med-Czech 2020; 65(09):1-7.

[7] Sales G, Giffoni BB, Barata PCR. Incidental catch of sea turtles by the Brazilian pelagic longline fishery. J. Mar. Biolog. Assoc. 2008 Aug;88(4):853-64.

[8] Orós J, Torrent A, Calabuig P, Déniz S. Diseases and causes of mortality among sea turtles stranded in the Canary Islands, Spain (1998-2001). Dis. Aquat. Organ. 2005 Jan 25;63(1):13-24.

[9] Guebert FM, Barletta M, Costa MF. Threats to sea turtle populations in the Western Atlantic: poaching and mortality in small-scale fishery gears. J. Coast. Res. 2013 Jan 2;65:42-7.

[10] Goldberg DW, Almeida DT, Tognin F, Lopez GG, Pizetta GTD, Leite Júnior NO, Sforza R. Hopper dredging impacts on sea turtles on the northern coast of Rio de Janeiro State, Brazil. Mar. Turt. Newsl. 2015;147(1):16-20.

[11] Hazel J, Gyuris E. Vessel-related mortality of sea turtles in Queensland, Australia. Wildlife Res. 2006 Apr 12;33(2):149-54.

[12] Hirth HF. Synopsis of the biological data on Green Turtle Chelonia mydas. Washington: United States Fish and Wildlife Service; 1997.

[13] Work PA, Sapp AL, Scott DW, Dodd MG. Influence of small vessel operation and propulsion system on loggerhead sea turtle injuries. J. Exp. Mar. Biol. Ecol. 2010 Sep 30;393(12):168-75. 
[14] Domiciano IG, Domit C, Bracarense APFRL. The green turtle Chelonia mydas as a marine and coastal environmental sentinels: anthropogenic activities and diseases. Semin. 2017 Sep;38(5):3417-34.

[15] Van der Hoop JM, Vanderlaan ASM, Taggart CT. Absolute probability estimates of lethal vessel strikes to North Atlantic right whales in Roseway Basin, Scotian Shelf. Ecol. Appl. 2012 Oct;22(7):2021-33.

[16] Frantzis A, Leaper R, Alexiadou P, Prospathopoulos A, Lekkas D. Shipping routes through core habitat of endangered sperm whales along the Hellenic Trench, Greece: Can we reduce collision risks? Plos One 2019 Feb 27;14(2):e0212016.

[17] Schoeman RP., Patterson-Abrolat C, Plön S. A Global Review of Vessel Collisions With Marine Animals. Front. Mar. Sci. 2020 May 19;7(292):1-25.

[18] Richards J. Metal Bridges - A new technique of turtle shell repair. J. Herpetol. Med. Surg. 2001;11(4):31-4.

[19] Hazel J, Lawler IR, Marsh H, Robson S. Vessel speed increases collision risk for the green turtle Chelonia mydas. Endanger. Species Res. 2007 Jun 29;3(1):105-13.

[20] Bonner BB. Chelonian Therapeutics. Vet. Clin. North Am. Exot. Anim. Pract. 2000 Jan 1;3(1):257-332.

[21] Mitchell MA, Diaz-Figueroa O. Wound management in reptiles. Vet. Clin. North Am. Exot. Anim. Pract. 2004;7(1):123-40.

[22] Lafortune M, Wellehan JF, Heard DJ, Rooney-Delpino E, Fiorello CV,
Jacobson ER. Vacuum-assisted closure (turtle VAC) in the management of traumatic shell defects in chelonians. J. Herpetol. Med. Surg. 2005;15(4):4-8.

[23] Haddad MCL, Bruschi LC, Martins EAP. Influência do açúcar no processo de cicatrização de incisões cirúrgicas infectadas. Rev.latino-am.enfermagem 2000 Jan;8(1):57-65. Portuguese.

[24] Newton H. Using sugar paste to heal postoperative wounds. Nurs. Times 2000 Sep 7;96(36 suppl):15-6.

[25] Candido LC. Novas abordagens no tratamento de feridas. São Paulo, SP: Editora SENAC; 2001.

[26] Prado-Guirro ECB, Puntel FC, Bebber BA, Thomas LD, Luiz RM, Viott AM. Efeito do açúcar em diferentes formulações na cicatrização por segunda intenção em ratos Wistar. Rev. Vet. Foc. 2015 Jul-Dec;13(1):1-8. Portuguese.

[27] Rosskopf WJ, Woerpel RW. Repair of shell damage in tortoises. Mod. Vet. Pract. 1981 Dec;62(12):938-93.

[28] Mcarthur S, Meyer J, Innis C. Anatomy and physiology. In: Mcarthur S, Wilkinson R, Meyer J, editors. Medicine and surgery of tortoises and turtles. Oxford: Blackwell; 2004. pp. 3571.

Conflict of interest: The authors declared no potential conflicts of interest concerning the research, authorship and publication of this article.

Acknowledgements: We are grateful to the medical team of the Jeronimo DixHuit Rosado Maia Veterinary Hospital, to the Federal Rural University of the Semi-Arid Region (Universidade 
Federal Rural do Semi-Árido UFERSA), to the Tamar Project (Tamar Center - ICMBio), to the partners Paulo Lara and Mari Oshiro, and to the company Azul Linhas Aéreas Brasileiras SA, essential for rescuing and transporting the animal from the Archipelago of Fernando de Noronha to the mainland. Radan Elvis Matias de Oliveira doctoral student of the Postgraduate Program in Animal Science (PPGCA) at the Federal Rural University of the Semi-Arid (UFERSA), thanks the Coordination for the Improvement of Higher Education Personnel (CAPES, Financial Code 001).

Funding: None.

How to cite this article: Freire $A C B$, Oliveira REM, Pires JML, Attademo FLN, Moreira AB, Melo LIS, Dantas MAM, Farias DSD, Bomfim AC, Bellini C, Gavilan SA, Silva FJL. Rehabilitation of a green sea turtle (Chelonia mydas) after collision with motorboat in the archipelago of Fernando de Noronha, Brazil. Brazilian Journal of Case Reports. 2021Jul-Sep;01(3):116-124. 